\title{
Optimasi Dosis Pemupukan Kalium pada Budi Daya Tomat (Lycopersicon esculentum) di Inceptisol Dramaga
}

\author{
Optimizing Dosage of Potassium Fertilizer for Tomato (Lycopersicum esculentum) Cultivation \\ in Inceptisol Dramaga
}

\section{Helena Ayu Permata Hati dan Anas D Susila*}

Departemen Agronomi dan Hortikultura, Fakultas Pertanian, Institut Pertanian Bogor (Bogor Agricultural University), Jl. Meranti, Kampus IPB Darmaga, Bogor 16680, Indonesia Telp. \& Faks. 62-251-8629353 e-mail agronipb@indo.net.id

*Penulis korespondensi: anasdsusila@ ymail.com

Disetujui 1 November 2016/ Published online 6 November 2016

\begin{abstract}
This research objective was to find the optimum rate of potassium fertilizer for specific location of tomato cultivation in Inceptisol Dramaga with high soil potassium content. The experiment was conducted at Cikabayan Teaching Farm IPB from July to October 2014. The experiment was arranged in Randomized Complete Block Design with four replications and single treatment factor which was potassium rate in five levels i.e. OX (0), 1/4X (152.2 $\left.\mathrm{kg} \mathrm{ha}^{-1}\right), 1 / 2 X\left(304.3 \mathrm{~kg} \mathrm{ha}^{-1}\right), 3 / 4 \mathrm{X}\left(456.3 \mathrm{~kg} \mathrm{ha}^{-1}\right)$, and $\mathrm{X}\left(608.6 \mathrm{~kg} \mathrm{ha}^{-1}\right)$. The results showed that on high soil potassium content potassium fertilizer were not affect all of the parameters, therefore Kfertilization is unnecessary.
\end{abstract}

Keywords: inceptisol, nutrient rate, optimation, potassium

\begin{abstract}
ABSTRAK
Penelitian ini bertujuan memperoleh dosis optimum pupuk kalium pada budi daya tomat spesifik lokasi yaitu di Inceptisol Dramaga dengan status hara $K$ tanah tinggi. Penelitian dilaksanakan di Kebun Percobaan Cikabayan IPB Dramaga mulai Juli hingga Oktober 2014. Rancangan Lingkungan yang digunakan adalah Rancangan Kelompok Lengkap Teracak dengan empat kali pengulangan dan satu faktor yaitu dosis pemupukan $\mathrm{K} 2 \mathrm{O}$ yang terdiri dari lima taraf yaitu OX (0), 1/4X (152.2 $\left.\mathrm{kg} \mathrm{ha}^{-1}\right), 1 / 2 X(304.3$ $\left.\mathrm{kg} \mathrm{ha}^{-1}\right), 3 / 4 \mathrm{X}\left(456.3 \mathrm{~kg} \mathrm{ha}^{-1}\right)$, dan X $\left(608.6 \mathrm{~kg} \mathrm{ha}^{-1}\right)$. Hasil penelitian menunjukkan bahwa pada status hara $\mathrm{K}$ tinggi pupuk $K$ tidak memberikan pengaruh nyata terhadap seluruh parameter pengamatan, sehingga pemupukan $\mathrm{K} 2 \mathrm{O}$ tidak perlu dilakukan.
\end{abstract}

Kata kunci: inceptisol, kalium, optimasi, status hara 


\section{PENDAHULUAN}

Tomat merupakan salah satu tanaman sayuran yang banyak dikonsumsi di Indonesia. Konsumsi tomat rumah tangga dari tahun 20072011 secara berurut adalah 2.091, 2.232, 1.971, $1.935,2.091 \mathrm{~kg}$ per kapita. Rata-rata peningkatan konsumsi tomat sayur rumah tangga dari tahun 2007 hingga 2011 adalah sebesar $0.32 \%$ (Pusdatin, 2012). Peningkatan ini tidak diimbangi dengan produksi dan produktivitas tomat yang konstan. Produksi tomat di Indonesia dari tahun 2009-2013 secara berurutan adalah 853.061, 891.616, 954.046, 893.463, dan 992.780 ton, sedangkan produktivitas tomat dari tahun 20092013 adalah 15.27, 14.58, 16.65, 15.75, dan 16.61 ton $\mathrm{ha}^{-1}$ (Kementan, 2013). Angka tersebut menunjukkan bahwa produksi dan produktivitas tomat belum stabil karena teknik pemupukan petani yang belum maksimal. Pemupukan diberikan untuk mencukupi kebutuhan hara tanaman yang tidak dapat disediakan oleh tanah. Pupuk tidak dapat diberikan dengan dosis rekomendasi umum akan tetapi berbeda untuk setiap jenis tanah, karena pada dasarnya setiap tanah memiliki kandungan hara tertentu yang berbeda.

Pemupukan yang efisien adalah pemupukan yang dilakukan dengan filosofi Nutrient Sufficiency Level, yaitu penambahan hara pada tanah sejumlah kebutuhan tanaman yang tidak mampu disediakan oleh tanah (Amisnaipa et al., 2009). Pemupukan yang diberikan dengan dosis yang optimum sesuai dengan kondisi hara tanah akan menghasilkan produksi tanaman tomat yang maksimum, selain itu juga dapat menghemat penggunaan pupuk, serta mempertahankan kualitas lingkungan. Penelitian optimasi pemupukan untuk komoditas hortikultura di Indonesia berdasarkan analisis tanah belum banyak dilakukan.

Kalium sangat berperan dalam proses fotosintesis, efisiensi penggunaan air, mempertahankan turgor, aktivator berbagai enzim, sebagai penyusun protein dan karbohidrat pada tanaman. Selama pertumbuhan tanaman tomat, kalium berperan dalam pengerasan batang, penguatan akar, peningkatan kualitas buah, serta peningkatan ketahanan terhadap beberapa jenis hama, penyakit, dan kekeringan. Defisiensi kalium menyebabkan pertumbuhan kuncup terhenti dan mati, pertumbuan tanaman lemah, daun tua menunjukkan nekrosis, buah muda rontok, ukuran buah kecil, warna buah kehijauan, rasa buah kurang mengandung asam (Uexkull, 1979).
Penelitian Amisnaipa et al. (2009) menunjukkan bahwa secara signifikan berbagai status $\mathrm{K}$ tanah berdasarkan ketersediaan $\mathrm{K}$ tanah bagi tanaman, mempengaruhi tinggi dan bobot buah panen tomat, bahkan menjadi faktor pembatas pada tanaman tomat. Rekomendasi dosis optimum pupuk $\mathrm{K}$ pada kadar hara "sangat rendah" adalah $281.3 \mathrm{~kg} \mathrm{ha}^{-1} \mathrm{~K} 2 \mathrm{O}$ atau setara dengan $468.8 \mathrm{~kg} \mathrm{ha}^{-1} \mathrm{KCl}$ pada penelitian tersebut. Tanah dengan kandungan hara "rendah", dosis optimum pupuk $\mathrm{K}$ adalah $178.6 \mathrm{~K}_{2} \mathrm{O} \mathrm{kg} \mathrm{ha}{ }^{-1}$ atau setara dengan $297.7 \mathrm{~kg} \mathrm{ha}^{-1} \mathrm{KCl}$. Tanah dengan status hara $\mathrm{K}$ tinggi dan sangat tinggi tidak memerlukan penambahan pupuk $\mathrm{K}$ karena respon tanaman tomat tidak nyata.

Tahap pertama analisis hara tanah adalah uji korelasi yaitu penentuan metode ekstraksi hara terbaik untuk menentukan larutan terbaik yang dapat menunjukkan kandungan hara $\mathrm{K}$ tanah. Hasil penelitian dari Izhar et al. (2013) yang dilakukan pada tanaman tomat di University Farm IPB, Cikabayan, Dramaga, Bogor, menyatakan bahwa metode ekstraksi hara $\mathrm{K}$ tanah yang terbaik untuk tanaman tomat di Inceptisol adalah Truog. Penentuan ini berdasarkan nilai koefisien korelasi terbaik antara nilai $\mathrm{K}$ terekstrak dan hasil relatif, yaitu sebesar 0.7. Tahap kedua adalah uji kalibrasi untuk mengetahui hubungan hasil relatif tanaman dengan jumlah unsur hara yang tersedia di dalam tanah (Izhar dan Susila, 2010). Klasifikasi tanah berdasarkan hasil uji kalibrasi menjadi acuan penentuan rekomendasi dosis pemupukan. Uji kalibrasi ini didasarkan pada respon hasil relatif tomat terhadap dosis pupuk menggunakan analisis regresi. Kelas kategori kesuburan tanah dari penelitian Izhar et al. (2013) yaitu, kategori "sangat rendah" adalah pada $\mathrm{K} 2 \mathrm{O} \leq 42.8 \mathrm{ppm}$, kategori "rendah" adalah pada $\mathrm{K} 2 \mathrm{O}$ antara $>42.8$ - $\leq 113$ ppm, kategori "sedang" adalah pada K2O $>113$ - $\leq 191.6$ ppm, dan kategori "tinggi" pada $\mathrm{K} 2 \mathrm{O}>191.6$ ppm.

Dosis optimum yang direkomendasikan adalah dosis pupuk $\mathrm{K}$ untuk mendapatkan hasil maksimum. Rekomendasi pemupukan dibuat dengan menurunkan nilai erapan tanah menjadi beberapa dosis lebih rendah. Nilai erapan $\mathrm{K}$ tanah menurut penelitian Izhar et al. (2013) adalah sebesar $608.6 \mathrm{~kg} \mathrm{ha}^{-1}$. Penelitian lebih lanjut mengenai pembuatan rekomendasi pemupukan berdasarkan uji tanah seperti ini perlu dilakukan. Semakin sering penelitian ini dilakukan akan memperbaiki keakuratan rekomendasi dosis tersebut (Izhar, 2012).

Bahan tanam yang digunakan dalam penelitian ini adalah Tomat varietas Tymoti F1, yang merupakan jenis tomat determinate 
hibrida untuk dataran rendah-menengah pada iklim tropis. Keunggulan dari varietas ini adalah memiliki ketahanan terhadap iklim panas, penyakit $\mathrm{Bw}, \mathrm{GV}$, serta BER. Umur panen varietas ini cukup singkat yaitu 55-60 HST dan potensi hasil 50-60 ton ha ${ }^{-1}$, bobot per buah 40$50 \mathrm{~g}$, serta bobot per tanaman 3-3.5 kg.

Percobaan dilakukan pada tanah Inceptisol yang merupakan salah satu jenis tanah yang banyak digunakan untuk budi daya tomat dataran rendah. Berdasarkan penelitian Hilman et al. (2008), tanah Inceptisol mempunyai Ntotal, kadar basa yang dapat dipertukarkan, Ca, $\mathrm{Mg}$, K, dan $\mathrm{Na}$ yang sedang, sedangkan ketersediaan $\mathrm{P}$ rendah. Menurut penelitian yang diadakan di beberapa lokasi di Bogor ini, beberapa 39988.52 ha lahan untuk bertanam sayuran, 6337.79 ha $(15.85 \%)$ berstatus $\mathrm{K}$ sangat rendah, $12768.03(31.93 \%)$ berstatus K rendah, $17243.78(43.12 \%)$ berstatus K sedang, dan 3638.39 (9.10\%) berstatus K tinggi.

\section{BAHAN DAN METODE}

Kegiatan penelitian dilaksanakan mulai Juli hingga Oktober 2014 di Kebun Percobaan Institut Pertanian Bogor Cikabayan, Dramaga, Bogor. Analisis tanah dilakukan di Laboratorium Penelitian Kimia dan Uji Tanah, Balai Penelitian Tanah, Balai Besar Sumber Daya Lahan Pertanian, Cimanggu, Bogor. Bahan yang digunakan dalam penelitian ini yaitu benih tomat varietas Tymoti F1. Pupuk organik dan anorganik diberikan mengacu pada penelitian sebelumnya. Pupuk $\mathrm{KCl}(60 \% \mathrm{~K} 2 \mathrm{O})$ dalam beberapa dosis, pupuk Urea $(45 \% \mathrm{~N}) 200 \mathrm{~kg} \mathrm{ha}^{-1}$, pupuk SP-36 (36\% P2O5) $150 \mathrm{~kg} \mathrm{ha}^{-1}$, kapur dolomit 3 ton ha ${ }^{-1,}$ pupuk kandang 20 ton $\mathrm{ha}^{-1}$, pupuk daun $(6 \%$ Ntot, $20 \% \quad \mathrm{P} 2 \mathrm{O} 5, \quad 30 \% \quad \mathrm{~K} 2 \mathrm{O}, \quad 1 \% \quad \mathrm{MgSO} 4)$, insektisida berbahan aktif endosulfan $350 \mathrm{~g} \mathrm{~L}^{-1}$. Media yang digunakan untuk penyemaian adalah pupuk kandang. Peralatan yang digunakan dalam kegiatan penelitian ini adalah tray, peralatan pertanian, timbangan analitik, jangka sorong, cutter, serta hand refractometer.

Percobaan ini menggunakan rancangan lingkungan Rancangan Kelompok Lengkap Teracak (RKLT) dengan satu faktor yaitu dosis pupuk $\mathrm{K}$ yang diberikan dalam 5 taraf perlakuan yaitu $(0 X, 1 / 4 X, 1 / 2 X, 3 / 4 X, X)$. Nilai $X$ tersebut adalah nilai erapan $\mathrm{K} 2 \mathrm{O}$ tanah yaitu sebesar $608.6 \mathrm{~kg} \mathrm{ha}^{-1}$ (Izhar, 2012). Nilai erapan merupakan jumlah maksimum unsur hara dapat diserap oleh tanah. Percobaan dilakukan menggunakan 4 ulangan sehingga diperoleh sebanyak 20 satuan percobaan pada petakan dengan ukuran masing-masing $1.5 \times 5 \mathrm{~m}$. Masing- masing petakan terdiri dari 20 tanaman, sehingga total populasinya adalah 400 tanaman. Jumlah tanaman contoh yang diamati pada setiap petakan percobaan adalah 10 tanaman yang ditentukan secara acak, sehingga total jumlah tanaman contoh yang digunakan dalam percobaan ini adalah sebanyak 200 tanaman. Dosis pupuk Urea dan SP-36 mengacu pada penelitian Amisnaipa et al. (2009), sedangkan dosis pupuk $\mathrm{KCl}$ merupakan nilai erapan yang kemudian diturunkan sebanyak empat taraf, sehingga didapatkan lima taraf pupuk $\mathrm{KCl}$ untuk masingmasing perlakuan.

Percobaan ini dimulai dengan pengambilan sampel tanah untuk uji lengkap analisis kimia dan fisika tanah, yaitu tekstur tanah, $\mathrm{pH}$ tanah, bahan organik, P-tersedia, K-tersedia, dan kemasaman dapat tukar. Pengukuran K tanah menggunakan pengekstrak Truog sesuai hasil penelitian Izhar et al. (2013), sedangkan pengujian lainnya menggunakan metode umum yang dilakukan di laboratorium. Sampel tanah diambil dari 10 titik di lahan percobaan secara acak. Hasil pengukuran tingkat kesuburan tanah pada lahan percobaan ini selanjutnya akan menentukan kelas kategori kesuburan tanah yang mengacu pada hasil penelitian Izhar et al. (2013).

Pengolahan tanah dilakukan setelah pengujian, pembuatan petakan berukuran $1.5 \times 5$ $\mathrm{m}$, aplikasi pupuk dan kapur dolomit untuk meningkatkan kesuburan dan $\mathrm{pH}$ tanah. Tanah diinkubasi selama 2 minggu. Benih tomat disemai selama 28 hari di bawah sinar matahari yang tidak intensif, kemudian pindah tanam ke lahan. Bibit tanaman tomat ditanam dalam petakan dengan jarak tanam $50 \mathrm{~cm}$ dalam baris dan $60 \mathrm{~cm}$ antar baris dengan pola double row. Sehingga didapat 20 tanaman dalam satu petak dan secara keseluruhan terdapat 400 tanaman dari 5 petak dan 4 kelompok ulangan. Pupuk SP-36 diberikan $100 \%$ saat tanam, pupuk urea diberikan $50 \%$ saat tanam, $25 \%$ saat 3 MST dan $25 \%$ saat 6 MST, sedangkan 5 taraf pupuk $\mathrm{KCl}$ untuk masingmasing perlakuan, yaitu $0,1 / 4 \mathrm{X}, 1 / 2 \mathrm{X}, 3 / 4 \mathrm{X}$, dan $\mathrm{X}$ diberikan masing-masing $1 / 3$ dosis pada saat tanam, 3 MST, dan 6 MST.

Pengamatan dilakukan secara vegetatif dan pasca panen terhadap 10 tanaman contoh pada tiap petak. Secara vegetatif mulai 1 hingga 8 MST satu kali setiap minggu, yaitu pada tinggi tanaman dan jumlah daun. Pengamatan tinggi tanaman dilakukan dengan menggunakan meteran, pengamatan jumlah daun dilakukan dengan cara menghitung secara manual. Penyiangan gulma dilakukan hanya saat sebelum pemupukan pada 3 dan 6 MST. Perompesan dilakukan pada 4, 6, dan 8 MST. Panen dilakukan mulai 60 HST pada buah 
yang merah $>80 \%$. Pemanenan dilakukan setiap 3 hari sekali pada pagi atau sore hari. Pengamatan panen yang dilakukan adalah pengukuran bobot per buah, bobot buah per tanaman, diameter, dan tinggi buah, serta PTT buah. Bobot buah ditimbang dengan timbangan analitik kemudian dipisahkan antara yang layak pasar dan tidak layak pasar dengan kriteria ukuran dan kecacatan buah. Diameter dan tinggi buah diukur dengan menggunakan jangka sorong. PTT buah diukur dengan menggunakan hand refractometer.

Data dianalisis statistik menggunakan uji $\mathrm{F}$ pada taraf $5 \%$, apabila berpengaruh nyata dilakukan uji lanjut ortogonal polinomial untuk melihat responnya.

\section{HASIL DAN PEMBAHASAN}

\section{Kondisi Umum}

Curah hujan saat dilakukan penelitian pada bulan Agustus $538 \mathrm{~mm}$, September $73.0 \mathrm{~mm}$, sedangkan pada bulan Oktober adalah $180.3 \mathrm{~mm}$. Temperatur rata-rata bulanan di daerah lokasi percobaan $25.7-26.8{ }^{\circ} \mathrm{C}$, namun suhu malam hari berkisar $25.1-28.5{ }^{\circ} \mathrm{C}$. Kelembaban udara antara 73-80\% (BMKG, 2014). Hasil analisis tanah dapat dilihat pada Tabel 1.

Tabel 1. Hasil analisis awal kimia dan fisika tanah Inceptisol di Kebun Percobaan Cikabayan Dramaga

\begin{tabular}{|c|c|c|c|}
\hline Karakteristik & Nilai & Status & Metode Ekstraksi \\
\hline Tekstur & & & Pipet \\
\hline Pasir (\%) & 32 & & \\
\hline Debu $(\%)$ & 43 & & \\
\hline Liat $(\%)$ & 25 & & \\
\hline $\mathrm{pH}$ & & & $\mathrm{pH}$ meter \\
\hline $\mathrm{H} 2 \mathrm{O}(1: 5)$ & 4.2 & Masam & \\
\hline \multicolumn{4}{|l|}{ Bahan organik } \\
\hline $\mathrm{C}(\%)$ & 1.54 & Rendah & Walkley \& Black \\
\hline $\mathrm{N}(\%)$ & 0.15 & Rendah & Kjedahl \\
\hline $\mathrm{C} / \mathrm{N}$ & 10 & Rendah & \\
\hline P2O5 (ppm) & 48.3 & Tinggi & Bray 1 \\
\hline $\mathrm{K} 2 \mathrm{O}(\mathrm{ppm})$ & 231 & Tinggi & Truog \\
\hline Nilai Tukar Kation & & & NH4-Acetat $1 \mathrm{~N}, \mathrm{pH} 7$ \\
\hline $\mathrm{Ca}(\mathrm{cmolc} / \mathrm{kg})$ & 5.80 & Sedang & \\
\hline $\mathrm{Mg}(\mathrm{cmolc} / \mathrm{kg})$ & 0.95 & Rendah & \\
\hline $\mathrm{K}(\mathrm{cmolc} / \mathrm{kg})$ & 0.45 & Rendah & \\
\hline $\mathrm{Na}(\mathrm{cmolc} / \mathrm{kg})$ & 0.20 & Sangat rendah & \\
\hline KTK (cmolc/kg) & 15.66 & Rendah & \\
\hline $\mathrm{KB}(\%)$ & 47 & Sedang & \\
\hline Kemasaman & & & $\mathrm{KCl} 1 \mathrm{~N}$ \\
\hline $\mathrm{Al} 3+(\mathrm{cmolc} / \mathrm{kg})$ & 1.18 & & \\
\hline $\mathrm{H}+(\mathrm{cmolc} / \mathrm{kg})$ & 0.32 & & \\
\hline
\end{tabular}

Berdasarkan hasil analisis contoh tanah oleh Laboratorium Balai Penelitian Tanah terhadap contoh kering $105^{\circ} \mathrm{C}$

Berdasarkan hasil uji $\mathrm{K} 2 \mathrm{O}$ dengan pengekstrak Truog kandungan $\mathrm{K} 2 \mathrm{O}$ lokasi penelitian sebesar $231 \mathrm{ppm}$ termasuk dalam kategori tinggi. Penentuan ini mengacu pada hasil uji kalibrasi yang dilakukan Izhar et al. (2013) (Tabel 2).

Persentase tanaman yang mati pada akhir penelitian adalah $18 \%$ dari populasi 400 tanaman, sehingga jumlah tanaman akhir adalah 328 tanaman. Jumlah ini masih cukup mewakili keseluruhan tanaman. Namun kesalahan teknik budidaya yaitu dilakukannya perompesan serta kurang sesuainya kondisi lingkungan

menyebabkan hasil yang didapat lebih kecil dari yang seharusnya seperti pada deskripsi varietas.
Tabel 2. Klasifikasi kategori ketersediaan hara K dengan ekstraktan Truog

\begin{tabular}{cc}
\hline Kategori & Kandungan $\mathrm{K}_{2} \mathrm{O}(\mathrm{ppm})$ \\
\hline Sangat rendah & $\leq 42.8$ \\
Rendah & $>42,8-\leq 113$ \\
Sedang & $>113-\leq 191,6$ \\
Tinggi & $>191,6$ \\
\hline
\end{tabular}

\section{Tinggi Tanaman}

Hasil uji statistik di bawah ini (Tabel 3) menunjukkan bahwa $\mathrm{K}_{2} \mathrm{O}$ tidak memberikan pengaruh yang nyata pada tinggi tanaman mulai minggu pertama hingga minggu kedelapan karena lokasi percobaan dilakukan telah memiliki kandungan kalium yang tinggi. 


\section{Jumlah Daun}

Jumlah daun menurun pada 6 MST dan kembali bertambah pada 8 MST (Tabel 4). Hal ini disebabkan oleh tidak stabilnya curah hujan yang mempengaruhi ketersediaan air. Kandungan $\mathrm{K}$ tanah yang tinggi juga menyebabkan tidak adanya respon nyata jumlah daun terhadap penambahan $\mathrm{K} 2 \mathrm{O}$.

Tabel 3. Respon rata-rata tinggi tanaman selama 8 MST terhadap penambahan K2O dalam 5 taraf dosis

\begin{tabular}{|c|c|c|c|c|c|c|c|c|}
\hline \multirow{2}{*}{$\begin{array}{l}\text { Penambahan } \\
\mathrm{K} 2 \mathrm{O}\left(\mathrm{kg} \mathrm{ha}^{-1}\right)\end{array}$} & \multicolumn{8}{|c|}{ Tinggi tanaman $(\mathrm{cm})$ pada umur (MST) } \\
\hline & 1 & 2 & 3 & 4 & 5 & 6 & 7 & 8 \\
\hline $0(0 X)$ & 7.38 & 10.92 & 17.917 & 26.72 & 36.22 & 47.17 & 47.28 & 48.88 \\
\hline $152.2(1 / 4 X)$ & 7.98 & 11.72 & 19.233 & 28.37 & 38.65 & 47.12 & 50.40 & 51.44 \\
\hline $304.3(1 / 2 X)$ & 7.00 & 10.70 & 18.350 & 27.83 & 37.37 & 49.13 & 52.37 & 53.00 \\
\hline $456.5(3 / 4 X)$ & 7.53 & 11.61 & 19.950 & 30.70 & 42.93 & 51.25 & 53.73 & 53.83 \\
\hline $608.6(\mathrm{X})$ & 6.80 & 9.87 & 14.517 & 22.32 & 34.82 & 44.46 & 50.83 & 52.15 \\
\hline $\mathrm{F}$ test $^{\mathrm{a}}$ & tn & tn & tn & tn & $\operatorname{tn}$ & $\operatorname{tn}$ & tn & tn \\
\hline
\end{tabular}

Uji F menunjukkan respon tinggi tanaman terhadap penambahan $\mathrm{K} 2 \mathrm{O}$; $\mathrm{tn}=$ tidak berbeda nyata

Tabel 4. Respon rata-rata jumlah daun selama 8 MST terhadap penambahan K2O sebanyak 5 taraf dosis

\begin{tabular}{|c|c|c|c|c|c|c|c|c|}
\hline \multirow{2}{*}{$\begin{array}{l}\text { Penambahan } \\
\mathrm{K} 2 \mathrm{O}\left(\mathrm{kg} \mathrm{ha}^{-1}\right)\end{array}$} & \multicolumn{8}{|c|}{ Jumlah daun pada umur (MST) } \\
\hline & 1 & 2 & 3 & 4 & 5 & 6 & 7 & 8 \\
\hline $0(0 \mathrm{X})$ & 4.17 & 6.30 & 8.00 & 9.36 & 10.42 & 8.93 & 8.67 & 9.36 \\
\hline $152.2(1 / 4 \mathrm{X})$ & 4.43 & 6.40 & 8.27 & 10.00 & 10.20 & 10.03 & 9.67 & 10.37 \\
\hline $304.3(1 / 2 X)$ & 4.53 & 6.40 & 8.37 & 9.90 & 10.67 & 10.20 & 9.13 & 10.93 \\
\hline $456.5(3 / 4 X)$ & 4.90 & 6.73 & 8.60 & 10.33 & 12.33 & 10.50 & 9.63 & 9.77 \\
\hline $608.6(\mathrm{X})$ & 3.97 & 5.27 & 7.00 & 8.87 & 10.50 & 10.17 & 9.60 & 9.89 \\
\hline $\mathrm{F}$ test $^{\mathrm{a}}$ & tn & $\operatorname{tn}$ & tn & tn & tn & tn & tn & tn \\
\hline
\end{tabular}

Uji F menunjukkan respon jumlah daun terhadap penambahan $\mathrm{K} 2 \mathrm{O}$; $\mathrm{tn}=$ tidak berbeda nyata

\section{Pengamatan Panen}

Berdasarkan hasil statistika (Tabel 5), perlakuan dosis $\mathrm{K} 2 \mathrm{O}$ yang diberikan tidak menunjukkan pengaruh yang nyata pada bobot per buah dan bobot buah per tanaman. Hasil tersebut juga tidak sesuai dengan deskripsi varietas tomat
Tymoti F1 yang menyatakan bahwa bobot per buah adalah 40-50 g, dan bobot buah per tanaman adalah 3-3.5 kg. Hal ini disebabkan kurang sesuainya kondisi lingkungan untuk pembentukan buah serta teknik budi daya yang tidak tepat, yaitu dilakukannya perompesan.

Tabel 5. Pengaruh dosis $\mathrm{K} 2 \mathrm{O}$ terhadap beberapa parameter pengamatan panen

\begin{tabular}{|c|c|c|c|c|}
\hline Penambahan $\mathrm{K}_{2} \mathrm{O}\left(\mathrm{kg} \mathrm{ha}^{-1}\right)$ & $\begin{array}{l}\text { Bobot per } \\
\text { buah }(\mathrm{g})\end{array}$ & $\begin{array}{c}\text { Bobot buah per } \\
\text { tanaman }(\mathrm{g})\end{array}$ & $\begin{array}{l}\text { Diameter buah } \\
(\mathrm{mm})\end{array}$ & $\begin{array}{c}\text { Tinggi buah } \\
(\mathrm{mm})\end{array}$ \\
\hline $0(0 X)$ & 13.76 & 105.267 & 29.88 & 27.62 \\
\hline $152.2(1 / 4 \mathrm{X})$ & 14.63 & 142.333 & 31.16 & 27.57 \\
\hline $304.3(1 / 2 X)$ & 16.48 & 160.433 & 30.91 & 29.25 \\
\hline $456.5(3 / 4 X)$ & 15.59 & 158.000 & 30.15 & 28.65 \\
\hline $608.6(X)$ & 15.39 & 177.200 & 29.22 & 28.21 \\
\hline $\mathrm{F}$ test $^{\mathrm{a}}$ & tn & tn & tn & tn \\
\hline
\end{tabular}

Uji F menunjukkan respon bobot per buah, bobot buah per tanaman, diameter buah, serta tinggi buah terhadap penambahan $\mathrm{K} 2 \mathrm{O}$; $\mathrm{tn}=$ tidak berbeda nyata

Suhu lapang terlalu tinggi untuk pembentukan dan pembesaran buah, serta rendahnya curah hujan menyebabkan kurangnya pasokan air untuk mengairi lahan. Kebutuhan air tanaman tomat terbesar adalah saat fase pembungaan sebanyak $185 \mathrm{~mm}$, serta pembuahan yaitu $93 \mathrm{~mm}$. Fase tersebut saat tanaman berumur sekitar 4-8 MST (Kurnia, 2004). Fase tersebut pada penelitian ini terjadi saat memasuki musim kering, sehingga pasokan air yang diberikan sangat tidak mencukupi kebutuhan tanaman. Akibatnya produksi buah sedikit dan ukuran buah kecil.

Terlihat bahwa hasil statistik menunjukan tidak ada pengaruh dosis $\mathrm{K} 2 \mathrm{O}$ terhadap diameter buah dan tinggi buah pada setiap perlakuan penambahan pupuk K2O (Tabel 5). Hasil ini sesuai dengan penelitian Luthfyrakhman dan Susila (2013) yang 
melaporkan bahwa diameter buah tomat tidak dipengaruhi oleh perlakuan dosis pupuk anorganik maupun pupuk kandang ayam.

Tabel 6. Pengaruh penambahan $\mathrm{K} 2 \mathrm{O}$ dalam 5 taraf terhadap kandungan Padatan Total Terlarut (PTT) buah

\begin{tabular}{lc}
\hline \multicolumn{1}{c}{ Penambahan K2O $\left(\mathrm{kg} \mathrm{ha}^{-1}\right)$} & PTT $\left({ }^{0}\right.$ Brix $)$ \\
\hline $0(0 \mathrm{X})$ & 7.30 \\
$152.2(1 / 4 \mathrm{X})$ & 7.03 \\
$304.3(1 / 2 \mathrm{X})$ & 7.20 \\
$456.5(3 / 4 \mathrm{X})$ & 7.43 \\
$608.6(\mathrm{X})$ & 6.90 \\
F test & th \\
\hline
\end{tabular}

Uji F menunjukkan respon PTT( $\left({ }^{\circ}\right.$ Brix $)$ terhadap penambahan $\mathrm{K} 2 \mathrm{O}$; $\mathrm{tn}=$ tidak berbeda nyata

Hasil uji PTT buah (Tabel 6) menunjukkan bahwa setiap perlakuan tidak memberikan pengaruh nyata, PTT buah berkisar antara 7.00-7.30 ${ }^{0}$ Brix. Hasil serupa juga didapatkan dari penelitian Hartz (2005) yang menyatakan bahwa fertigasi kalium tidak mempengaruhi konsentrasi PTT tomat. Data pada Tabel 5 dan Tabel 6 merupakan hasil pengukuran terhadap panenan ketiga dan keempat. Alasan pemilihan sampel tersebut adalah karena buah tomat mulai terbentuk sempurna baik secara fisik maupun kandungan kimianya mulai dari tangkai buah ketiga, yang kurang lebih dipanen saat panenan ketiga dan keempat. Buah yang dipanen pada panen pertama dan kedua memiliki ukuran yang relatif kecil.

Penambahan $\mathrm{K} 2 \mathrm{O}$ tidak memberikan pengaruh yang nyata terhadap bobot buah layak pasar dan tidak layak pasar per petak dan perkiraan per hektar seperti yang disajikan pada Tabel 7. Pengelompokan layak pasar dan tidak layak pasar ini dilakukan berdasarkan bobot dan kondisi buah. Buah yang termasuk pada kategori layak pasar adalah buah dengan bobot $>17 \mathrm{~g}$ atau yang memiliki diameter buah $>30 \mathrm{~mm}$, serta kondisi buah segar dan tidak ada serangan hama (Codex, 2008).

Tabel 7. Respon rata-rata jumlah buah layak pasar dan tidak layak pasar per petak dan per hektar

\begin{tabular}{lcccc}
\hline \multicolumn{2}{r}{$\begin{array}{c}\text { Penambahan } \\
\mathrm{K}^{2} \mathrm{O}\left(\mathrm{kg} \mathrm{ha}^{-1}\right)\end{array}$} & \multicolumn{2}{c}{ Bobot buah per petak $\left(\mathrm{g}\left(7.5 \mathrm{~m}^{2}\right)^{-1}\right)$} & \multicolumn{2}{c}{ Bobot buah per ha $\left(\right.$ ton ha $\left.{ }^{-1}\right)$} \\
\cline { 2 - 5 } & Layak pasar & Tdak layak pasar & Layak pasar & Tidak layak pasar \\
\hline $0(0 \mathrm{X})$ & 812.97 & 589.24 & 1.08 & 0.79 \\
$152.2(1 / 4 \mathrm{X})$ & 1042.20 & 803.13 & 1.39 & 1.07 \\
$304.3(1 / 2 \mathrm{X})$ & 1383.26 & 687.93 & 1.84 & 0.92 \\
$456.5(3 / 4 \mathrm{X})$ & 1181.27 & 781.36 & 1.58 & 1.04 \\
$608.6(\mathrm{X})$ & 1062.78 & 529.88 & 1.42 & 0.71 \\
F test & tn & th & th & th
\end{tabular}

Uji F menunjukkan respon bobot buah dalam luasan petak dan perkiraan dalam satuan hektar terhadap penambahan K2O; tn= tidak berbeda nyata

Hasil yang tidak berbeda nyata antar perlakuan (Tabel 8) menunjukkan bahwa tanah yang sudah mengandung hara $\mathrm{K}$ dengan status tinggi $(231 \mathrm{ppm})$ tidak memerlukan tambahan pupuk $\mathrm{K}$ lagi. Perkiraan hasil dalam satuan hektar menunjukkan angka yang sangat kecil dibandingan dengan deskripsi varietas yaitu sebesar 50 ton $\mathrm{ha}^{-1}$. Interaksi pertumbuhan tanaman dengan lingkungan tumbuh yang kurang menguntungkan akan menyebabkan rendahnya produksi tanaman. Suhu lapang pada malam hari mencapai $28{ }^{0} \mathrm{C}$, kondisi ini tidak sesuai untuk penanaman tomat. Peet dan Bartholomew (1996) menyatakan tinggi tanaman, produksi bunga, dan buah rendah pada suhu malam hari $26{ }^{\circ} \mathrm{C}$.

Kebutuhan air terbesar tanaman tomat adalah saat fase pembungaan, yaitu $185 \mathrm{~mm}$, serta pembuahan yaitu $93 \mathrm{~mm}$. Fase tersebut adalah saat tanaman berumur sekitar 4-8 MST (Kurnia, 2004). Pada penelitian ini, fase tersebut terjadi saat memasuki musim kering. Akibatnya produksi buah sedikit dan ukuran buah kecil.
Tabel 8. Respon bobot buah total per petak dan per hektar terhadap dosis $\mathrm{K} 2 \mathrm{O}$

\begin{tabular}{lcc}
\hline \multirow{2}{*}{ Penambahan K2O $\left(\mathrm{kg} \mathrm{ha}^{-1}\right)$} & \multicolumn{2}{c}{ Bobot buah total } \\
\cline { 2 - 3 } $\mathrm{g}\left(7.5 \mathrm{~m}^{2}\right)^{-1}$ & ton $^{-1}$ \\
\hline $0(0 \mathrm{X})$ & 1402.21 & 1.87 \\
$152.2(1 / 4 \mathrm{X})$ & 1224.00 & 1.63 \\
$304.3(1 / 2 \mathrm{X})$ & 2071.18 & 2.76 \\
$456.5(3 / 4 \mathrm{X})$ & 1962.62 & 2.62 \\
$608.6(\mathrm{X})$ & 1592.66 & 2.12 \\
F test $^{\mathrm{a}}$ & th & tn
\end{tabular}

Uji $\mathrm{F}$ menunjukkan respon total bobot per petak dan per hektar terhadap penambahan $\mathrm{K} 2 \mathrm{O}$; $\mathrm{tn}=$ tidak berbeda nyata

Kesalahan teknis budi daya dalam percobaan ini adalah dilakukannya perompesan yang tidak seharusnya dilakukan pada jenis tanaman tomat determinate, yaitu memiliki pertumbuhan terbatas. Perawakan tanaman jenis ini adalah menyemak dengan beberapa cabang. Perompesan terhadap cabang- cabang tersebut menyebabkan tanaman hanya memiliki 1 atau 2 
batang utama saja. Akibatnya tanaman tidak dapat berproduksi maksimal.

\section{KESIMPULAN}

Aplikasi $\mathrm{K}_{2} \mathrm{O}$ dalam berbagai dosis tidak memberikan pengaruh yang nyata pada Inceptisol Dramaga dengan kandungan $\mathrm{K}_{2} \mathrm{O}$ tinggi yaitu 231 ppm, sehingga pada status hara ini pemupukan tidak perlu dilakukan.

\section{DAFTAR PUSTAKA}

Amisnaip, Susila, A.D., Situmorang, R., Purnomo, D.W. 2009. Penentuan kebutuhan pupuk kalium untuk budidaya tomat menggunakan irigasi tetes dan mulsa polyethylene. J.Agron. Indonesia 37(2): 115-122.

[BMKG] Badan Meteorologi dan Geofisika. 2014. Data Iklim. Bogor (ID): Stasiun Klimatologi Darmaga.

[Kementan] Kementrian Pertanian. 2013. Sub Sektor Hortikultura. Produksi dan Produktivitas Tomat menurut Provinsi 2009-2013. Tersedia pada: www.pertanian.go.id/ap_pages/mod/datah orti [diunduh 24 Desember 2014].

[Codex Stan] Codex Standart. 2008. Codex Standart For Tomatoes. Codex Stan 2932008.

Hartz, T.K.., Johnstone, P.R., Francis, D.M., Miyao, E.M. 2005. Processing tomato yield and fruit quality improved with potassium fertigation. Hort Science 40(6): 1862-1867.

Hilman, Y., Sutapradja, R. Rosliani, Y., Suryono. 2008, Status hara fosfat dan kalium di sentra sayuran dataran rendah. J. Hort 18(1):27-37.
Izhar, L., Susila, A.D. 2010. Rekomendasi pemupukan fosfor dan potasium berdasarkan analisis hara tanah pada tanaman sayuran. J. Hort. Indonesia 1(2):81-88.

Izhar, L., Susila, A.D., Purwoko, B.S., Sutandi, A., Mangku, I.W. 2012. Penentuan metode terbaik uji fosfor untuk tanaman tomat pada tanah inceptisol. J.Hort 22(2): 139-147.

Izhar, L., Susila, A.D., Purwoko, B.S., Sutandi, A., Mangku, I.W. 2013. Penentuan metode terbaik uji kalium untuk tanaman tomat pada tanah inceptisol. J. Hort 23(3):218-224.

Kurnia, U. 2004. Prospek pengairan pertanian tanaman semusim lahan kering. $J$. Litbang Pertanian 23(4):130-138.

Luthfyrakhman, H., Susila, A.D. 2013. Optimasi dosis pupuk anorganik dan pupuk kandang ayam pada budidaya tomat hibrida (Lycopersicon esculentum Mill. L.). Bul. Agrohorti 1(1):119-126.

Peet, M.M., Bartholomew, M. 1996. Effect of night temperature on pollen characteristics, growth, and fruit set in tomato. J.Amer.Soc.Hort.Sci 121(3):514519.

[PUSDATIN] Pusat Data dan Sistem Informasi Pertanian. 2012. Statistik Konsumsi Pangan Tahun 2012. Tersedia pada: http://eksim.pertanian.go.id/tinymcpuk/ga mbar/file/ Statistik_Konsumsi_2012.pdf [diunduh 23 Des 2013].

Uexkull, H.R. 1979. Tomato: Nutrition and fertilizer requirements in the tropics. Di dalam : Cowell R, editor. First International Symposium on Tropical Tomato; 1978 Okt 23-27; Shanhua, Taiwan. Shanhua $(\mathrm{CN})$ : Asian Vegetable Research and Development Center. hlm 65-78. 